\title{
Policy For Crime Murder Investigation By The Children In Polrestabes Semarang
}

\author{
Erwin Chan $^{1}$ and Jawade Hafidz ${ }^{2}$
}

\begin{abstract}
Issues that will be examined are: 1) How do criminal investigations policy murders committed by children in Polrestabes Semarang today? 2) How is the investigation of criminal policy of murder committed by children who should have been in the Indonesian National Police?

This study uses empirical juridical approach method, the specifications in this research is descriptive. Data collection methods use primary data with interview techniques. The data analysis method used is the analysis of qualitative data.

The study concluded that: 1) Policy murder investigation of criminal offenses committed by children in Polrestabes Semarang today in addressing the crime of child offenders who commit criminal acts be routed into diversion pursuant to Act No. 11 of 2012 on the Criminal Justice System Child. 2) Policies murder investigation of criminal offenses committed by children who should at the Indonesian National Police should be able to: a) Understand the scope of the duties and authority of the Police Child Protection. b) know the Juvenile Justice Act, Child Protection Act, the Child Welfare Act and the UN Convention on the Rights of the Child. c) Ability to interpret and discuss the procedure done in dealing with children in conflict with the law.

Keywords: Policies; Investigation; Children Crime.
\end{abstract}

\section{Introduction}

A child can become a person who is good or evil is influenced by the experience he had experienced in his development. If children have a good life experience, then he'll be a good boy. But if the experience of life gained by a child of a crime, it is likely he will be a vicious one. The phenomenon of increasing acts of violence committed behavior as if the child is not directly proportional to the age of the offender. ${ }^{3}$

The key task of the Indonesian National Police (INP) under article 13 of Law of the Republic of Indonesia No. 2 of 2002 on the Police (Law 2 of 22) are:(1) maintaining security and public order; (2) to enforce the law, and (3) provide protection, shelter and services to the community. Based on the second main task is to enforce the law, the police carry out an investigation of the offenses committed by children.

Crime by the perpetrator of minors continue to be processed under the procedures of the law. But the difference is the prosecution process using juvenile justice system. In principle Act No. 11 of 2012 has been using a model of restorative justice centered on the diversion process as efforts to resolve criminal offenses committed by children. As mentioned in Article 5 point 3 of Act No. 11 of 2012 explains that the juvenile justice system based on the principles of protection and justice shall be pursued so that the diversion process. As mentioned in Article 5 point 3 of Act No. 11 of 2012 explains that

\footnotetext{
${ }^{1}$ Student of Master of Law, Universitas Islam Sultan Agung Semarang and Police Academy of Semarang, Email : erwinsiregar0204@gmail.com

${ }^{2}$ Lecturer of Master of Law, Sultan Agung Islamic University (UNISSULA), Semarang

${ }^{3}$ Nandang Sambas, 2010, Pembaharuan Sistem Pemidanaan Anak di Indonesia, Graha IImu, Yogyakarta, p. 103.
} 
the juvenile justice system based on the principles of protection and justice shall be pursued so that the diversion process. In Article 7 paragraph 2 of Act No. 11 of 2012 also set about implementing provisions of diversion, that the offenses committed: (1) is punishable by imprisonment under the 7 (seven) years; and (2) is not a repetition of criminal acts.

Along with the acts of violence committed by children, there is a serious criminal offense to a penalty of more than seven (7) year from the child actors. As the incidence of murder of a driver "Gocar" named alm. Deni Setiawan performed by two people on behalf of the IBR vocational students aged 15 years and 15 years of age DIR in Semarang, Central Java. ${ }^{4}$ In the process of criminal investigation with child offenders, the police as law enforcers more peace efforts with the approach of restorative justice approach, which is implemented by way of diversion. However, if done by children is the crime of murder and threatened with criminal penalties of more than seven (7) years as practiced by IBR (15 years) and DIR (15 years) in the jurisdiction of Polrestabes Semarang, then the investigation should be continued by investigators.

Based on the description above, the writer interested to study and examine more deeply and poured into a shaped writing a thesis entitled "Policy For Crime Murder Investigation By The Children In Polrestabes Semarang".

The formulation of the problem in this research: How to policy murder investigation of criminal offenses committed by children in Polrestabes Semarang today?; How to policy murder investigation of criminal offenses committed by children who should at the Indonesian National Police?

\section{Research methods}

The approach used in this study, using empirical means yurudic method in this study that examined the main ingredient is the primary legal materials secondary law, and tertiary legal materials. ${ }^{5}$ Specifications in this research is descriptive. Descriptive research is a research method that aims to describe the systematic and accurate account of the facts and characteristics of the area concerned.

The data used in this research is the primary data source, secondary, and tertiary. The primary data source is an object that is observed directly in the field and informants were interviewed. Secondary law consists of: Act No. 2 of 2002 on the Indonesian National Police, Act No. 11 of 2012 on Child Criminal Justice System, and the Police Regulation No. 6 of 2019 concerning the Crime Investigation. Tertiary legal materials consist of a dictionary, encyclopedia.

Data collection methods used to obtain data that have a relationship with the object of research that informant interviews and review of documents, while the data analysis method used is the analysis of qualitative data in this study include data reduction, data and conclusions / verification.

\section{Results and Discussion}

\footnotetext{
4 https://www.tribunnews.com/metropolitan/2018/01/24/2-siswa-smk-di-semarang-bunuh-sopir-gocarlalu-mencuri-mobilnya, Accessed on March 1, 2020 10:00.

${ }^{5}$ Ngani Nico, 2012, Metodologi Penelitian dan Penulisan Hukum. Pustaka Yustisia, Jakarta, p. 179
} 


\subsection{Crime Murder Investigation Policy Conducted By Children In Polrestabes Semarang}

The rise of the crime of murder is required roles and duties of the authorities including the police, judiciary and Justice. ${ }^{6}$ Murder committed intentionally in the form of goods contained in Article 338 of the Criminal Code which formulation is "person who deliberately take the life of another person convicted of murder by a maximum imprisonment of 15 years".

Three motifs that each background property or the economy, power, and social relationships. One motive could be the reason for the offender to commit murder. "In fact, could the three motifs that occur in a murder case," Murder can be caused by things that are light and spontaneity. For example, because the perpetrators provoked emotions so high that he had dark eyes and murder.

Crime is a term that is familiar in the life of society, basically the crime term given to a particular act or a particular human behavior that can be considered as something evil. Actions or behavior assessed and gets a reaction that is not liked by the people, it is an action that is not allowed to appear in the middle of people's lives as well as murder. As under Article 338 of the Criminal Code which reads "Whoever intentionally taking the life of others convicted of murder by a maximum imprisonment of 15 years." And in Article 340 of the Criminal Code on premeditated murder, which reads: "Whoever knowingly and with a plan in advance depriving another person's life.

Cases of crimes involving children as perpetrators of crime brings its own phenomenon. Given the child is emotionally unstable individual who was already subject to the law, the handling of criminal cases with child offenders need special attention, starting from the criminal procedural law applicable to the child. Child Criminal procedural law specifically regulates the obligations and rights acquired children.

One legal protection against criminal acts committed perpetrators of child is Application of Restorative Justice, namely the completion of the criminal case Children, involving offenders, victims, families perpetrator / victim, and other relevant parties to work together to find a fair settlement with the emphasis on restoring back on the original state, and not retaliation.

Efforts legal protection offenses done through diversion among child actors. Diversion is the settlement of children from the criminal justice process to the outside of the criminal justice process.

Here is a flow chart of diversion in the investigation of criminal offenses committed by children in the jurisdiction of Polrestabes Semarang:

\footnotetext{
${ }^{6}$ Adami Chazawi, 2010, Kejahatan Terhadap Tubuh Dan Nyawa, Raja Grafindo Persada, Jakarta, p.56
} 


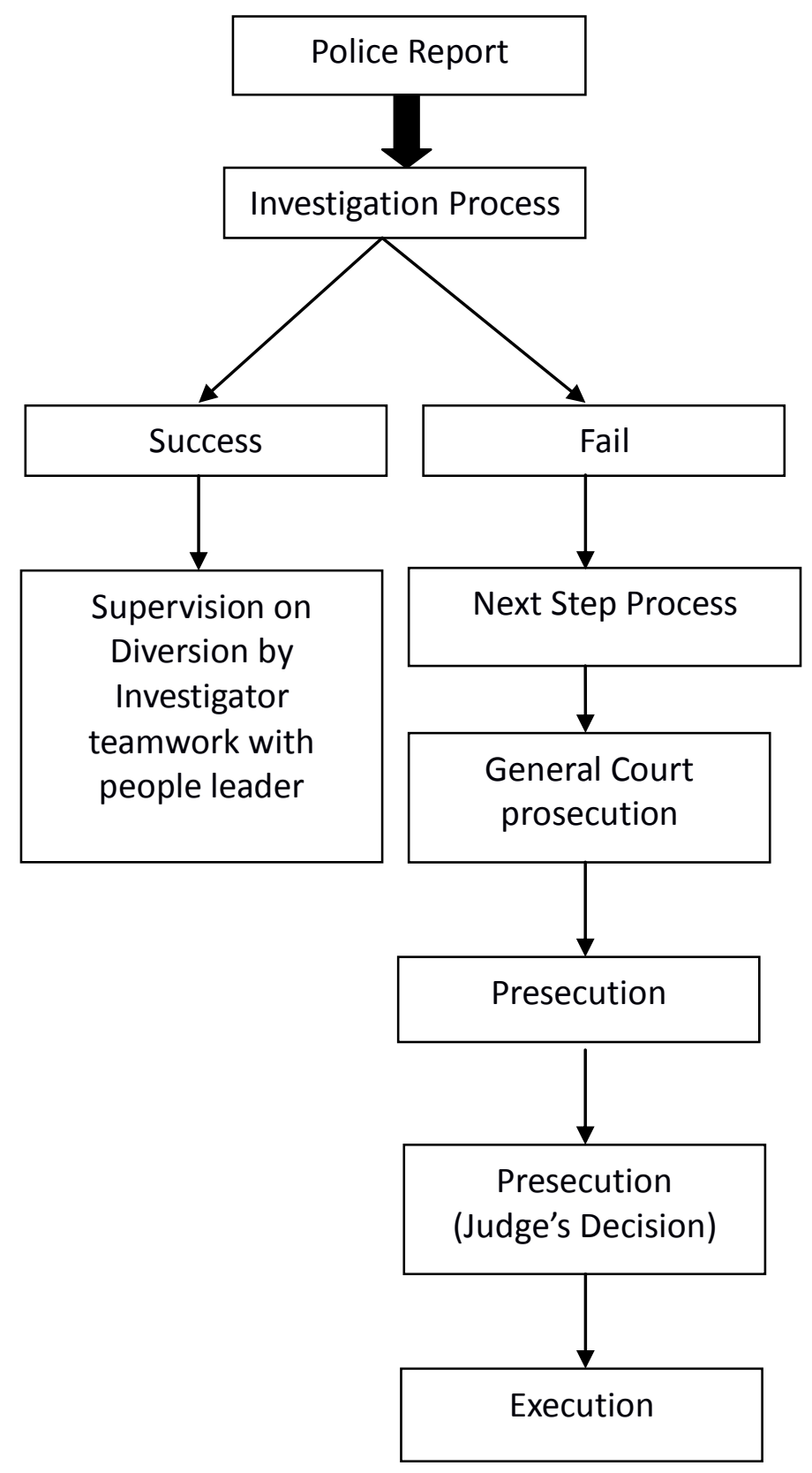

Here is the data criminal acts performed by children in the region of Polrestabes Semarang from 2014-2019: 
Table 1

Total Crime conducted by Children

Managed by the Criminal Investigation

Unit PPA Sat Reskrim Polrestabes Semarang of 2014-2019

\begin{tabular}{|c|c|c|c|c|c|c|c|c|}
\hline No. & Crime Type & Article & 2014 & 2015 & 2016 & 2017 & 2018 & 2019 \\
\hline 1 & $\begin{array}{l}\text { Physical of } \\
\text { violence } \\
\text { against } \\
\text { children }\end{array}$ & $\begin{array}{c}76 \text { C jo } 80 \\
\text { BAL }\end{array}$ & $\begin{array}{c}5(3 \\
\text { finished), } 1 \\
\text { (Q21), } 1 \\
\text { (Investigatio } \\
\text { n) }\end{array}$ & $\begin{array}{c}2 \text { (1 } \\
\text { complete } \\
\text { ), (1 } \\
\text { Investigat } \\
\text { ion) }\end{array}$ & 1 (Q21) & $\begin{array}{c}1 \\
\text { (diversion } \\
1\end{array}$ & $\begin{array}{c}2 \\
\text { (diversion } \\
\text { ) }\end{array}$ & naught \\
\hline 2 & maltreatment & $\begin{array}{c}351 \text { of the } \\
\text { Criminal } \\
\text { Code }\end{array}$ & & & & & & \\
\hline 3 & $\begin{array}{c}\text { Intercourse } \\
\text { against } \\
\text { children }\end{array}$ & $\begin{array}{c}76 \text { D jo } 81 \\
\text { BAL }\end{array}$ & $\begin{array}{c}1 \\
\text { (completed) }\end{array}$ & $\begin{array}{c}3 \\
(2 \\
\text { complete } \\
\text { d) }\end{array}$ & $3(\mathrm{Q} 21$ & & $\begin{array}{c}1 \\
\text { (complet } \\
\text { ed) }\end{array}$ & \\
\hline 4 & $\begin{array}{c}\text { Fornication } \\
\text { against } \\
\text { children }\end{array}$ & $\begin{array}{c}76 \text { E jo } 82 \\
\text { BAL }\end{array}$ & $\begin{array}{c}1 \\
\text { (Investigatio } \\
n)\end{array}$ & & 1 (Q21) & & & \\
\hline 5 & beatings & $\begin{array}{l}170 \text { of the } \\
\text { Criminal } \\
\text { Code }\end{array}$ & 1 (Q21) & & & $\begin{array}{c}2 \\
\text { (complet } \\
\text { e) }\end{array}$ & & \\
\hline 6 & Insult & $\begin{array}{l}310 \text { of the } \\
\text { Criminal } \\
\text { Code }\end{array}$ & & & & & & \\
\hline 7 & Theft & $\begin{array}{c}362 / 363 \text { of } \\
\text { the Penal } \\
\text { Code }\end{array}$ & & $\begin{array}{c}2 \\
\text { (diversion } \\
\text { ) }\end{array}$ & $\begin{array}{c}1 \\
\text { (complet } \\
\text { ed) } \\
\end{array}$ & $\begin{array}{c}1 \\
\text { (complet } \\
\text { ed) }\end{array}$ & & \\
\hline 8 & $\begin{array}{l}\text { Carry off } \\
\text { children }\end{array}$ & $\begin{array}{l}332 \text { of the } \\
\text { Criminal } \\
\text { Code }\end{array}$ & $\begin{array}{c}3 \\
(2 \\
\text { completed) } \\
1 \\
\text { (Investigatio } \\
\text { n) }\end{array}$ & & $\begin{array}{c}1 \\
\text { (complet } \\
\text { ed) }\end{array}$ & & & \\
\hline 9 & $\begin{array}{c}\text { Bring Sharp } \\
\text { Weapon }\end{array}$ & $\begin{array}{l}2 \text { Markets } \\
\text { Emergenc } \\
\text { y Act } 1951\end{array}$ & & & & & & \\
\hline 10 & Participate & $\begin{array}{l}55 \text { of the } \\
\text { Criminal } \\
\text { Code }\end{array}$ & 1 (diversion) & & & & & \\
\hline
\end{tabular}

Based on the homicides committed by child offenders in Polrestabes Semarang are felonies with a penalty of more than seven (7) year from the child actors. However, if done by children is the crime of murder and threatened with criminal penalties of more than seven (7) years as practiced by IBR (15 years) and DIR (15 years) in the jurisdiction of Polrestabes Semarang, then the investigation should be continued by investigators.

The enactment of Act No. 11 of 2012 on Child Criminal Justice System (SPPA) clarify the roles of law enforcement officers in the handling of juvenile criminal cases by prioritizing the protection of children through a restorative justice approach. 


\subsection{Crime Murder Investigation Policy Conducted By Children Who Should Be In The Indonesian National Police}

Based on the fact that the future should be in the working environment of Polrestabes Semarang be able to: ${ }^{7}$

- Understanding the scope of the duties and authority of the Police Child Protection. In order to understanding the scope of duties and authorities of the investigator maid on the protection of children should be required to be implemented for the future by making a breakthrough that is expected to ensure a child's perspective is not just as a criminal but a child's perspective from the viewpoint of a child as victims. And the view from the perspective of children. Their viewpoints are owned by the investigator aides is expected to create a restorative justice. Restorative justice is done in order to avoid a stigmatization of children in conflict with the law is a bad boy who is obliged to answer for his actions requested of a judge and must carry out the punishment in a prison.

By having an idea of the importance of restorative justice is expected that all law enforcement officials, especially the investigator maid criminal offense child can avoid an investigation process that uses violence against children and or perform actions that endanger children's maneuver both in terms of mental, physical or psychological. Investigator child should be able to understand that in a process of investigation will this child be in the future not only be pursued in an effort to criminal liability, but more than that, in the stage of investigation of children, children in conflict with the law have a moral responsibility to be corrected so that the child does not repeat the same action for the second time.

- Knowing the Juvenile Justice Act, Child Protection Act, the Child Welfare Act and the UN Convention on the Rights of the Child

The role of the investigator maid child in a child investigation process, expected to be able to understand the child's condition. It is possible with a view to include children as part of a man who needs to get protection for himself and other rights held with the hope to create an ongoing investigation in the absence of violence against child and keep the child in the context of child protection, welfare children and the protection of children's rights.

- Able to translate and discuss the procedure done in dealing with children in conflict with the law.

In the framework of the investigation on the brat, as mandated by the Juvenile Justice Act for future, investigator attendants will be able to provide a view that is used in the investigations on the child. This implies that there is a renewal of an investigation procedure better in the hope the child does not feel placed as a child who must be accountable for its criminal actions according to the child so that the sanction is the revenge of a particular state.

- Being able to respond to the measures taken by the investigator aides to discuss the problems of children in conflict with the law.

\footnotetext{
7 Interview with Inspector Dhaneswari, SIK, Kanit PPA Polrestabes Semarang, Thursday, March 26, 2020, $12.00 \mathrm{pm}$.
} 
In discussing the measures taken by the investigator maid child, it is necessary in the event to discuss the problems faced by children require attention of the investigator maid. This of course affects the mindset of the child and can be made possible as a solution to understand the problems of children in conflict with the law. Policies that taken by the investigator maid child is to impose a diversion and discretion as well as other training involving institutions that pay attention to the child.

\section{Closing}

\subsection{Conclusion}

- Policies murder investigation of criminal offenses committed by children in Polrestabes Semarang today in addressing the crime of child offenders who commit more criminal acts continued to be versioned in Act No. 11 of 2012 on the Criminal Justice System Children with restorative justice.

- Policies murder investigation of criminal offenses committed by children who should at the Indonesian National Police be able to:

- Understanding the scope of the duties and authority of the Police Child Protection.

- Knowing the Juvenile Justice Act, Child Protection Act, the Child Welfare Act and the UN Convention on the Rights of the Child.

- Able to translate and discuss the procedure done in dealing with children in conflict with the law.

- Being able to respond to the measures taken by the investigator aides to discuss the problems of children in conflict with the law.

\subsection{Suggestion}

- In the case of children of law enforcement officers from the level of investigation, prosecution up to the examination of a court diversion efforts should endeavor to have children first.

- Law enforcement agencies should optimally use Act No. 23 of 2002 on Child Protection.

- Expected to society more increase social control and the need for parental supervision on environment and socially children.

\section{References}

[1] Adami Chazawi, 2010, Kejahatan Terhadap Tubuh Dan Nyawa, Raja Grafindo Persada, Jakarta.

[2] Fernando M. Manullang, 2012, Menggapai Hukum Berkeadilan Tinjauan Hukum Kodrat dan Antitomi Nilai. Kompas Media Nusantara, Jakarta.

[3] Maidin Gultom, 2014, Perlindungan Hukum Terhadap Anak dalam Sistem Peradilan Anak di Indonesia. Refika Aditama, Bandung.

[4] Nandang Sambas, 2010, Pembaharuan Sistem Pemidanaan Anak di Indonesia, Graha Ilmu, Yogyakarta. 
[5] Ngani Nico, 2012, Metodologi Penelitian dan Penulisan Hukum. Pustaka Yustisia, Jakarta.

[6] Wagiati Soetodjo, 2015. Hukum Pidana Anak. Refika Aditama, Bandung.

[7] Act No. 2 of 2002 on the Indonesian National Police

[8] Act No. 23 of 2002 on the Protection of Children

[9] Act No. 11 of 2012 on the Criminal Justice System Children

[10] Act No. 17 of 2016 on the second amendment to Act No. 23 of 2002 regarding Child Protection.

[11] Decree of the President of the Republic of Indonesia, No. 36 of 1990 concerning the Ratification of Convention on the Rights of the Child (Convention on the Rights of the Child). 